\title{
Measurement of intact parathormone during operation for primary hyperparathyroidism
}

\author{
Libansky $\mathrm{P}^{1}$, Adamek $\mathrm{S}^{1}$, Broulik $\mathrm{P}^{2}$, Fialova $\mathrm{M}^{1}$, Kubinyi $\mathrm{J}^{3}$, Sedy $\mathrm{J}^{4}$, Pafko $\mathrm{P}^{1}$, Yershov $\mathrm{D}^{5}$, Lischke $\mathrm{R}^{1}$ \\ Third Department of Surgery, First Faculty of Medicine, Charles University in Prague and University Hospital \\ Motol, Prague, Czech Republic. petr.libansky2@fnmotol.cz
}

\begin{abstract}
In this prospective study, the role of the intact parathormone (iPHT) levels for the verification of pathologic parathyroid tissue removal during parathyroidectomy, was analyzed in 441 patients diagnosed with primary hyperparathyroidism. The level of intact parathormone was obtained before the initial incision (baseline level) and 10 minutes after the pathologic parathyroid gland removal (control value). In $80 \%$ of cases, the decrease of intact parathormone was more than $50 \%$ of the baseline level. The comparison of preoperative and postoperative intact parathormone levels can also be used as marker of parathyroid hyperplasia or persistent hyperparathyroidism. This method is necessary mainly for performance of focused, miniinvasive approaches as well as in reoperations. This method is of significant benefit in cases of negative preoperative examination methods. The determination of intact parathormone level increases the success of parathyroidectomy (Ref. 26). Text in PDF www.elis.sk. KEY WORDS: primary hyperparathyroidism, intact parathormone, parathyroidectomy, surgery, human.
\end{abstract}

\section{Introduction}

Primary hyperparathyroidism is one of the most common endocrine conditions. PHPT is being diagnosed with increasing frequency mainly as the result of the introduction of routine serum calcium measurements. The cause of the primary hyperparathyroidism is a hyperfunction of one or more parathyroid glands, caused by adenoma, hyperplasia or rarely, a carcinoma. Clinically, it represents a disorder of calcium, phosphate and bone metabolism, often leading to biochemical, renal and bone syndrome. Patients with primary hyperparathyroidism significantly more often suffer from gastroduodenal ulcers, pancreatitis or cholecystolithiasis than normal population (Broulík et al, 2011, 2015). Other disorders, such as: muscle weakness or neuropsychiatric diseases can occur as well. Moreover, hypercalcaemia negatively influences the heart and blood circulation. Primary hyperparathyroidism can be also asymptomatic, at least in initial stages. The diagnosis is based on finding the hypercalcaemia, hypophosphataemia and increased level of parathor-

\footnotetext{
${ }^{1}$ Third Department of Surgery, First Faculty of Medicine, Charles University in Prague and University Hospital Motol, Prague, Czech Republic, ${ }^{2}$ Third Department of Medicine, Department of Endocrinology and Metabolism, First Faculty of Medicine, Charles University in Prague and General University Hospital in Prague, Prague, Czech Republic, ${ }^{3}$ Institute of Nuclear Medicine, First Faculty of Medicine, Charles University in Prague and General University Hospital in Prague, Prague, Czech Republic, ${ }^{4}$ Department of Anatomy, Faculty of Medicine and Dentistry, Palacky University Olomouc, Czech Republic, and ${ }^{5}$ Institute of Anatomy, First Faculty of Medicine, Charles University in Prague, Prague, Czech Republic

Address for correspondence: P. Libansky, MD, PhD, Third Department of Surgery, First Faculty of Medicine, Charles University in Prague and University Hospital Motol, Prague, V Uvalu 84, CZ-150 06 Praha 5 Motol, Czech Republic.

Phone: +420.224438001
}

mone in serum. Moreover, these patients have an increased activity of alkaline phosphatase, hypercalciuria and hyperphosphaturia.

In case of a clear diagnosis, a surgical treatment, based on the removal of the pathologically changed parathyroid tissue, is indicated (Naňka et al, 2006). Preoperatively, maximum effort to localize particular parathyroid tissue, most often by sonography or scintigraphy, is necessary (Libánský et al, 2008). Surgical treatment, parathyroidectomy, is definitive, curative and relatively safe. During the operation, the main goal is to remove the proper pathologic parathyroid tissue (Libánský et al, 2008). The success of pathologic parathyroid gland removal is verified by histology or, nowadays, more often by an intact parathormone (iPHT) level measurement (Schneider et al, 2014, Irvin et al, 2004). In case of an experienced surgeon, preoperative or postoperative complications are rare and mortality rate is very low. Major postoperative complications include paresis of the recurrent laryngeal nerve or persistent postoperative hypocalcaemia (Adámek et al, 2005). A persistent hyperparathyroidism represents an important complication as well. In order to prevent it the level of intact parathormone measurement during the operation has been recommended (Schneider et al, 2014, Irvin et al, 2004).

\section{Material and methods}

Together, 481 patients were operated for primary hyperparathyroidism in the Third Department of Surgery in Motol Hospital, Prague, between January 2012 and January 2015. In 441 of them, who were included into this prospective study, the level of intact parathormone was measured during the operation. Inclusion criteria were set as: (i) patient with the preoperative diagnosis of primary hyperparathyroidism, (ii) patient indicated for parathyroidectomy, (iii) patient operated in the Department of Surgery in Motol Hospi- 


\section{5-257}

tal, Prague and (iv) patient with a complete documentation during the preoperative, operative and postoperative period. Patients who did not match all inclusion criteria were excluded from the study.

All surgeries were performed in general anaesthesia. Bilateral neck exploration was done, as described previously (Adámek et al, 2005). In brief, on neck, collar skin incision followed by midline incision and in some cases, partial sternotomy, videothoracoscopy or video-assisted mediastinoscopy was performed (Libánský et al, 2016 a,b). Superficial neck fascia was cut in midline, infrahyoid muscles pulled laterally, lobes of the thyroid gland were detached from surrounding structures and pulled medially. Both recurrent laryngeal nerve and inferior thyroid artery were identified. Close to the site of crossing of recurrent laryngeal nerve and inferior thyroid artery, majority of parathyroid glands were found. If not, they were identified in other regions, where ectopic parathyroid tissue might occur, in relation to preoperative localization methods and results of our previous anatomical study (Naňka et al, 2006).

The first blood sample was taken before the incision. The level of intact parathormone obtained, served as a baseline level, as recommended by Irvin et al (2004) and Kaczirek et al (2005). Second blood sample was taken 10 minutes after the pathologic parathyroid gland was removed. When the decrease of intact parathormone was more than $50 \%$ of the original value, this measurement was taken as diagnostic for the proper parathyroid gland removal, i.e. the surgical success (Prager et al, 2003, Riss et al, 2013). All samples were analyzed in the Department of Clinical Biochemistry, Second Faculty of Medicine and Teaching Hospital Motol, Prague, employing laboratory machine Roche Cobas e411 with a specific kit for the statim iPTH measurement. In our laboratory, the reference values for intact parathormone were set as $1-7 \mathrm{pmol} / \mathrm{L}(10-65 \mathrm{pg} / \mathrm{mL})$. The success of the operation was set as a decrease of total calcium levels in 48 hours after surgery.

All values are reported as the mean \pm S.E.M. Statistical significance $(p<0.05)$ between intact parathormone levels before and after the operation was compared using the paired Student's t-test $(\mathrm{p}<0.05)$.

\section{Results}

During past three years, together 882 blood samples in 441 patients were successfully examined and the levels of intact parathormone measured. From these 441 patients, 376 (85.26\%) were females and $65(14.74 \%)$ were males. The mean age of patients was $60.52 \pm 8.25$ years. From this sample, 119 patients $(26.98 \%)$ had renal syndrome, 203 patients $(46.03 \%$ ) had bone syndrome, 31 patients ( $7.03 \%)$ had gastroduodenal ulcer, 9 patients $(2.04 \%)$ had pancrea titis, 110 patients $(24.94 \%)$ had cholecystolithiasis, 44 patients (9.98 \%) suffered from psychiatric disorders, 238 patients (53.97\%) had arterial hypertension and only 49 patients $(11.11 \%)$ had no signs of other disease in their medical history. The mean value of total calcium before the operation was $2.76 \pm 1.11 \mathrm{mmol} / \mathrm{L}$, the mean value of intact parathormone before the operation was $19.53 \pm 11.48 \mathrm{pmol} / \mathrm{L}$.

The mean level of intact parathormone before the incision was $19.72 \pm 12.45 \mathrm{pmol} / \mathrm{L}$ (range $1.77-222.2 \mathrm{pmol} / \mathrm{L}$ ). The mean value of intact parathormone after the operation was $6.50 \pm 4.98 \mathrm{pmol} / \mathrm{L}$ (range $0.74-50.85 \mathrm{pmol} / \mathrm{L}$; in one case $156.5 \mathrm{pmol} / \mathrm{L}$ - see be- low). This difference has been significant ( $\mathrm{p}<0.05$ ). In 354 cases $(80.27 \%)$, the decrease of intact parathormone was more than $50 \%$ of the original value. In 85 cases $(19.27 \%$ ), the intact parathormone level decreased as well, but not more than $50 \%$. In two cases $(0.45 \%)$, even an increase of intact parathormone was observed; however, in all these 87 cases $(19.73 \%)$, the total calcium levels decreased significantly. In 13 cases $(2.95 \%)$, the level of intact parathormone was originally below $6 \mathrm{pmol} / \mathrm{L}$, so any significant decrease could have not been found. In four cases $(0.91 \%)$, no significant decrease of intact parathormone and calcium levels was found. In one case, the parathyroid carcinoma was found. This patient was re-operated afterwards. In one patient, the preoperative level of intact parathormone was $159.5 \mathrm{pmol} / \mathrm{L}$ and postoperative value was $156.5 \mathrm{pmol} / \mathrm{L}$. In this patient, the generalization of clavicular neuroendocrine carcinoma with positivity of parathormone in tumor cells was found during the operation. The decrease of calcium levels below $2.5 \mathrm{mmol} / \mathrm{L}$ after the operation were not found in 20 patients $(4.54 \%)$. From these, in 7 patients the calcium levels decreased in the following day, in one case there was a neuroendocrine tumor, in one case there was a parathyroid carcinoma.

Postoperative hypocalcaemia with paresthesia occurred in 87 cases $(19.73 \%)$, where the oral or intravenous calcium substitutes were administered. In two cases $(0.45 \%)$, the patient was re-operated. In one case $(0.23 \%)$, due to a severe general health status, the reoperation was contraindicated. During the postoperative period, no permanent hypocalcaemia was found. The drain was removed in the mean $1.88 \pm 0.95$ postoperative day. Patients were released home in day $2.86 \pm 1.98$.

\section{Discussion}

Women were affected significantly more often than men (ratio $5.8: 1$ ), which is in accordance with other studies (Broulík et al, 2011, Miller et al, 2008). The sampling of blood for the analysis of intact parathormone levels is currently used as a marker whether the pathologically changed parathyroid tissue was removed (Riss et al, $2007 \mathrm{~b}, 2009$ ). The decrease in parathyroid hormone level during operation was most predictive of cure of primary hyperparathyroidism (Davis et al, 2013). Peroperative measurement of intact parathormone levels and their comparison can prevent the unfortunate leaving of pathologically changed parathyroid gland in the body of the patient. Moreover, the persistent parathyroid hyperplasia can be prevented. In our sample, together three patients have persistent hypercalcaemia, from which one had parathyroid carcinoma and one neuroendocrine clavicular carcinoma.

The success of the operation with the intact parathormone level measurement was $99.10 \%$. When compared to previous years, this modification increased the success of the operation for 0.50 $\%$ (Adámek et al, 2005). For the measurement of intact parathormone, different criteria exist (Barczynski et al, 2009). The blood sample is taken before the surgical incision and after the parathyroid gland removal (Riss et al, 2007a). Some authors report the association of intraoperative parathormone level over $4.24 \mathrm{pmol} /$ $/ \mathrm{mL}$ with an increased risk of persistence and recurrence in primary hyperparathyroidism (Rajaei et al, 2015). The persistence 
of an increased intact parathormone has been reported to occur in $8-40 \%$ of cases. For example, Wang et al (2005) reports that to occur in $15 \%$ of cases. The persistence of increased parathormone level can be caused by vitamin D insufficiency as well. The injection of furosemid stimulates PTH secretion in healthy adults (Muller, 2015). The measurement of peroperative intact parathormone levels should be performed during miniinvasive approaches on parathyroid glands (Joliat et al, 2015). This method is associated with a significant decrease of (i) operation time, (ii) length of hospitalization, and (iii) occurrence of complications including not esthetic scarring (Adámek et al, 2005, Libánský et al, 2007). Some authors propose the financial benefit of the approach (Barczynski et al, 2009), whereas others doubt it (Stalberg et al, 2006). The use of intact parathormone monitoring decreases the occurrence of postoperative hypercalcaemia and accelerates healing of the patient after the operation (Bergenfelz et al, 2009). Some authors propose that the level of preoperative intact parathormone positively correlate with the volume of pathologically changed parathyroid tissue and thus easier identification of scintigraphy is proposed (Biertho et al, 2004). Increased level of peroperative intact parathormone indicates a higher probability of persistent primary hyperparathyroidism (Schneider et al, 2014).

The determination of intact parathormone level during the operation can be used as a marker of proper pathologic parathyroid tissue removal. Such operation should be performed in specialized centers, equipped with devices necessary for quick and routine intact parathormone level measurements.

\section{References}

1. Adámek S, Libánský P, Nanka O, Sedý J, Pafko P. Surgical therapy of primary hyperparathyroidism and it's complications. Experience with 453 patients. Zbl Chir 2005; 130: 109-113.

2. Barczynski M, Konturek A, Hubalewska-Dydejczyk A, Cichon S, Nowak W. Evaluation of Halle, Miami, Rome, and Vienna intraoperative iPTH assay criteria in guiding minimally invasive parathyroidectomy. Langenbecks Arch Surg 2009; 394: 843-849.

3. Bergenfelz AO, Jansson SK, Wallin GK, Mårtensson HG, Rasmussen L, Eriksson HL, Reihnér EI. Impact of modern techniques on short-term outcome after surgery for primary hyperparathyroidism: a multicenter study comprising 2,708 patients. Langenbecks Arch Surg 2009; 394: 851-860.

4. Biertho LD, Kim C, Wu HS, Unger P, Inabnet WB. Relationship between sestamibi uptake, parathyroid hormone assay, and nuclear morphology in primary hyperparathyroidism. J Am Coll Surg 2004; 199: 229-233.

5. Broulik PD, Brouliková A, Adámek S, Libanský P, Tvrdoň J, Broulikova K, Kubinyi J. Improvement of hypertension after parathyroidectomy of patients suffering from primary hyperparathyroidism. Int J Endocrinol 2011; 2011: 309068 .

6. Broulík P, Adámek S, Libánský P, Kubinyi J. Changes in the Pattern of Primary Hyperparathyroidism in Czech Republic. Prague Med Rep 2015; 116: $112-121$

7. Davis DD, Tee MC, Kowal J, Holmes DT, Wiseman SM. Streamlining of intra-operative parathyroid hormone, measurements for cure during parathyroidectomy. The American Journal of Surgery 2013; 205: 597-601.

8. Irvin GL 3rd, Solorzano CC, Carneiro DM. Quick intraoperative parathyroid hormone assay: surgical adjunct to allow limited parathyroidectomy, improve success rate, and predict outcome. World J Surg 2004; 28: 1287-1292.
9. Joliat G-R, Demartines N, Portmann L, Boubaker A. Successful minimally invasive surgery for primary hyperparathyroidism: influence of preoperative imaging and intraoperative parathyroid hormone levels. Langenbecks Arch Surg 2015; 400: 937-944.

10. Kaczirek K, Riss P, Wunderer G, Prager G, Asari R, Scheuba C, Bieglmayer C, Niederle B. Quick PTH assay cannot predict incomplete parathyroidectomy in patients with renal hyperparathyroidism. Surgery 2005; 137: 431-435.

11. Libánský P, Adámek S, Sedý J, Pafko $\mathbf{P}$, Nanka $\mathbf{O}$. Preliminary experience in minimally invasive video assissted parathyroidectomy. Rozhl Chir 2007; 86: 457-460.

12. Libánský P, Astl J, Adámek S, Nanka O, Pafko P, Spacková J, Foltán R, Sedý J. Surgical treatment of primary hyperparathyroidism in children: report of 10 cases. Int J Pediatr Otorhinolaryngol 2008; 72: 1177-1182.

13. Libánský P, Broulík P, Fialová M, Kubinyi J, Lischke R, Táborská D, Tvrdoň J, Šedý J, Adámek S. Videothoracoscopic excision of mediastinal parathyroid adenoma in primary hyperparathyroidism. Rozhl Chir 2016; 95: 245-248.

14. Libánský P, Yershov D, Adámek S, Šimonek J, Fialová M, Kubinyi J, Lischke R. Video-assisted mediastinoscopic removal of ectopic parathyroid adenoma combined with standard cervical exploration. European Surgery-Acta Chirurgica Austriaca 2016; 48: 315-317.

15. Miller BS, Dimick J, Wainess R, Burney RE. Age- and sex-related incidence of surgically treated primary hyperparathyroidism. World J Surg 2008; 32: 795-799.

16. Muller ME, Ogna VF, Maillard M, Stoudmann C, Zweiacker C, Anex Ch, Wuerzner G, Burnier M, Bonny O. Furosemide stimulation of parathormone in humans: role of the calcium-sensing receptor and the renin-angiotensin system. Pflugers Arch - Eur J Physiol 2015; 2413-2421.

17. Nanka O, Šedý J, Vítková I, Libánský P, Adámek S. Surgical anatomy of parathyroid glands with emphasis on parathyroidectomy. Prague Med Rep 2006; 107: 261-272.

18. Prager G, Riss P, Bieglmayer C, Niederle B. The role of intraoperative quick PTH measurements in primary hyperparathyroidism. Ann Ital Chir 2003; 74: 395-399.

19. Rajaei MH, Bentz AM, Schneider DF, Sippel RS, Chen H, Oltmann SC. Justified follow-up: a final intraoperative parathyroid hormone (ioPTH) Over $40 \mathrm{pg} / \mathrm{mL}$ is associated with an increased risk of persistence and recurrence in primary hyperparathyroidism. Ann Surg Oncol 2015; 22: 454-459.

20. Riss P, Kaczirek K, Heinz G, Bieglmayer C, Niederle B. A "defined baseline" in PTH monitoring increases surgical success in patients with multiple gland disease. Surgery 2007; 142: 398-404.

21. Riss P, Kaczirek K, Bieglmayer C, Niederle B. PTH spikes during parathyroid exploration - a possible pitfall during PTH monitoring? Langenbecks Arch Surg 2007; 392: 427-430.

22. Riss P, Asari R, Scheuba C, Bieglmayer C, Niederle B. PTH secretion of "manipulated" parathyroid adenomas. Langenbecks Arch Surg 2009; 394: 891-895.

23. Riss P, Krall C, Scheuba C, Bieglmayer C, Niederle B. Risk factors for "PTH spikes" during surgery for primary hyperparathyroidism. Langenbecks Arch Surg 2013; 398: 881-886.

24. Schneider DF, Mazeh H, Chen H, Sippel RS. Predictors of recurrence in primary hyperparathyroidism: an analysis of 1386 cases. Ann Surg 2014; 259: 563-568.

25. Stalberg P, Sidhu S, Sywak M, Robinson B, Wilkinson M, Delbridge L. Intraoperative parathyroid hormone measurement during minimally invasive parathyroidectomy: does it "value-add" to decision-making? J Am Coll Surg 2006; 203: 1-6.

26. Wang TS1, Ostrower ST, Heller KS. Persistently elevated parathyroid hormone levels after parathyroid surgery. Surgery 2005; 138: 1130-1135.

Received May 4, 2016. Accepted January 4, 2017. 